\title{
Genotype Analysis of Human Papilloma Virus Infection in Accordance with Cytological Diagnoses
}

\author{
Mi-Suk Park ${ }^{1}$, Hyun-Wook Cho ${ }^{2}$, Jin-Gak Kim ${ }^{1}$, Nan-Young Bae ${ }^{1}$, Dong-Sun Oh ${ }^{1}$ and Ho-Hyun Park ${ }^{3}$ \\ ${ }^{1}$ Department of Clinical Laboratory Science, Gwangyang Health College, Gwangyang 545-703, Korea \\ ${ }^{2}$ Department of Biology, College of Bio-Industry Science, Sunchon National University, Suncheon 540-742, Korea \\ ${ }^{3}$ BioMedical Laboratory Science, Mokpo Science University, Mokpo 530-730, Korea
}

\begin{abstract}
We investigated whether multiple infections can be used as predictors of progression to carcinogenesis in accordance with the cytological diagnosis in women receiving abnormal cytologic diagnosis as analysis genotype and compared to single infection. HPV prevalence is highest in the age of under 30 years old woman, HPV prevalence is started to lower after 30 years old and started to increase over 60 years old as like a U-shape. The specific HPV genotypes is an important factor because increased single infection and reduced multiple infections and appeared single infection with $\mathrm{AC}$ in progressing carcinogenesis. HPV 16 revealed the statistical significance at the single infection in squamous cell lesions, and HPV 18 revealed the statistical significance at the single infection in adenocarcinoma with showed HPV 16, 58, 18, 52-type distribution.
\end{abstract}

Keywords: Cytological, Human papilloma virus, Genotype, Multiple infection

This is an Open Access article distributed under the terms of the Creative Commons Attribution Non-Commercial License (http://creativecommons.org/licenses/by-nc/3.0) which permits unrestricted non-commercial use, distribution, and reproduction in any medium, provided the original work is properly cited.

Copyright @ 2015 The Korean Society for Clinical Laboratory Science. All rights reserved.
Corresponding author: Mi-Suk Park Department of Clinical Laboratory Science, Gwangyang Health College, Gwangyang 545-703, Korea

Tel: 82-61-760-1451

E-mail: misuk0704@gy.ac.kr

Received: February 27, 2015

Revised: March 17, 2015

Accepted: March 18, 2015

\section{서 론}

자궁경부는 편평상피와 원주상피로 이루어져 있고 두 지점을 만 나는 곳을 편평-원주 상피 접합부라고 하며 자궁암 중에서 가장 많 은 부분을 차지하는 자궁경부암의 호발 부위이다. 자궁경부암의 위 험 인자로는 조기의 성경험, 다수의 성 상대자, 흡연, 구강피임제 복 용(Daling 등, 1996; Tolstrup 등, 2006)이지만 자궁경부암 발생의 주요 원인으로는 성 접촉에 의한 인유두종 바이러스(Human papilloma virus : HPV)로 자궁경부암에서 99\%가 나타났다 (Walboomers 등, 1999).

HPV는 180종의 유전자형(Soto-De Leon 등, 2011)이 있으며, $30 \sim 40$ 종의 유전자형이 여성생식기에 감염을 일으킨다. 각각의 유전자형들은 암을 유발하는 능력의 차이에 따라서 고위험군, 중등 도 위험군, 저위험군으로 분류된다(Lorincz 등, 1992). 이 분류는 $\mathrm{HPV} \mathrm{DNA}$ 가 숙주 세포 염색체에 삽입된 후 HPV의 E6, E7 유전자 가 작용하여 세포를 변형시키고 단백질들을 만들어 $\mathrm{p} 53$ 과 $\mathrm{pRb}$ (retinoblastoma protein)의 종양 억제 단백과 결합하여 불활 성화 시키는 능력에 따라 나눌 수 있다(Kim과 Lee, 1998; Lee 등,
2003).

p53 유전자는 종양 억제 유전자로서, 손상된 DNA의 수복과 세 포성장조절의 전사인자로 세포주기 중 G1 검문지점(checkpoint) 에 작용하여 세포자멸사와 세포주기의 조절에 관여하는데 $\mathrm{p} 53$ 의 돌연변이는 세포 증식 억제 기능을 상실하게 되어 여러 종류의 암 을 유도한다고 알려져 있다(Kastan 등, 1992; Lee 등, 2014). p53 단백은 정상조직에서 반감기가 짧아 면역조직화학검사에서 검출 할 수 없으나, 악성 조직에서는 반감기가 길어 검출할 수 있고 이것 은 p53 유전자가 돌연변이 되었다는 증거이다(Back, 2013).

$\mathrm{HPV}$ 에 감염된 여성들 중 20 50\%가 한 개 이상의 HPV 유전자 형의 감염을 보이며, 한 종류 이상의 고위험군 $\mathrm{HPV}$ 유전자형은 $99 \%$ 가 자궁경부암과 중등도 자궁경부 이형성증에서 발견 되는 것 으로 알려져 있다(Franco 등, 1999; Liaw 등, 2001; Yim 등, 2003). 단일감염과 비교하여 다중감염이 고등급 자궁경부 종양 형 성의 인자로 예측되며(Fife 등, 2001) 이러한 다중감염은 자궁경부 종양 환자들에게 많이 발견된다. 그리고 HPV 고위험군 유전자형 의 다중감염이 지속감염을 유발하여 HPV감염에 대한 면역력을 저 하시키므로 주요 인자로 볼 수 있다(Sasagawa 등, 2001). 
HPV 6, 11, 16, 18 유전자형이 백신으로 개발되었지만, 인종, 나 이, 지역에 따라 차이가 있으므로 유전자형의 빈도와 함께 단일감 염과 비교 시 자궁경부 종양의 주요 인자인 다중감염이 세포학적 진단에 따른 암화 과정으로 진행시 예측 인자로 사용할 수 있는지 알아보고자 하였다.

\section{재료 및 방법}

\section{1. 연구 대상}

2012년 1월 1일부터 2012년 12월 31일까지 광주 - 전남지역의 대학병원 병리과에 접수된 환자를 대상으로 하였다. 병리과로 접수 된 HPV DNA chip검사는 4,292건이었고 그 중 세포학적으로 비정 상적 진단을 받은 345 건이 대상이었다.

\section{2. 연구 방법}

자궁 경부에 Cytobrush를 이용하여 세포학적 검사를 시행하였 으며, 진단은 The Bethesta System (TBS) 보고 방법으로 사용하였 다. HPV 감염 유무는 전기영동 상에 밴드가 형성되면 양성, 형성되 지 않으면 음성으로 판독하였다. $\mathrm{HPV}$ 유전자형 검사는 My $\mathrm{HPV}$ chip kit (MyGene Company, Seoul, Korea)를 이용하여 고위험 군(High risk, HR) 15종류로 HPV 16, 18, 31, 33, 35, 39, 45, 51, 52, 53, 56, 58, 59, 66, 68형, 저위험군(Low risk, LR) 9종류로 $\mathrm{HPV} 6,11,34,40,42,43,44,54,70$ 형으로 24종의 HPV 유전자 형을 확인할 수 있다. 전기영동 상에 밴드를 보이면서 $\mathrm{My} \mathrm{HPV}$ DNA chip 슬라이드에 음성으로 나오면 24종 이외의 유전자형으 로 기타 위험군 유전자형(Other risk, OR)로 판정하였다.

\section{3. 통계학적 분석}

수집된 자료는 SPSS (version 18.0)을 이용하여 분석하였다. 연 구에 사용된 검체의 연령대와 HPV 감염된 유전자형 인자 수와 타 입 등의 $\mathrm{HPV}$ 단일/다중 감염 등의 상관관계를 $\chi^{2}$ 독립성 검증 (chi-square independence test)에 따른 교차분석을 실시하였다. 그리고 HPV 감염별 유전자형 및 연령대별과 세포학적 진단에 영향 을 미치는 위험요인을 선별하기 위한 여러 가지의 독립변수들에 대 한 양적인(quantitative) 척도보다는 질적인(qualitative) 척도의 통계방식이 필요했다. 이런 예측확률을 바탕으로 한 분류분석 기법 의 통계방식인 이분형 로지스틱 회귀분석(binary variable logistic regression)을 실시하였다. 세포학적 진단에 따른 다중 감염 수 및 $\mathrm{HPV}$ 감염 유전자형의 통계적 판별에서는 세포학적 진단을 종속변 수로 다중 감염 수 및 $\mathrm{HPV}$ 감염 유전자형을 독립변수로 가정하여 로지스틱 회귀분석을 실시하였다. 그리고 HPV 감염 유전자형과
나이대별의 분석에서는 각각 HPV 감염 유전자형을 종속변수로 나 이대를 독립변수로 가정하여 로지스틱 회귀분석을 실시하였다. 분 석에 따른 위험요인 선별 시 유의수준 $(p$ value)은 $p<0.05$ 로 정하 였고 유의수준을 만족하는 검체에서 신뢰구간을 확인하였다.

\section{결 과}

\section{1. 연령별 HPV 감염}

2012년 1월 1일부터 2012년 12월 31일까지 광주 • 전남지역의 대학병원 병리과에 의뢰한 HPV DNA chip검사 4,292건을 대상으 로 결과 분석을 하였다. 검사 환자들의 연령은 만 17 세에서 만 95 세 까지(평균 47.6세)로 17 29세 245건(5.7\%), 30 39세 860건 (20.0\%), 40 49세 1339건(31.2\%), 50 59세 1,107건(25.8\%), 60 95세 741건(17.3\%)이었다(Table 1).

$\mathrm{HPV}$ DNA chip 검사 결과 HPV 양성으로는 1,834건(42.7\%), 음성으로는 2,458 건(57.3\%)이었다. 1,834 건 중 연령별로 HPV 양 성은 17 29세 145건(59.2\%), 30 39세 384건(44.7\%), 40 49 세 527건(39.4\%), 50 59세 436건(39.4\%), 60 95세 342건 (46.2\%)이었다.

\section{2. 세포학적 진단에 따른 단일/다중 감염 분포}

$\mathrm{HPV}$ 감염 유전자형(단일/다중 감염)과 세포학적 진단과의 교차 분석 결과, 단일감염 중 고위험군 $\mathrm{HPV}$ 유전자형 분포가 세포학적 진단의 등급이 높을수록 즉, Low-grade squamous intraepithelial lesion (LSIL, 44.7\%), High-grade squamous intraepithelial lesion (HSIL, 67.5\%), Squamous cell carcinoma (SCC, 82.0\%) 순으로 증가하였다. 반면에 저위험군과 다른군에서는 세포학적 진 단의 등급이 높을수록 감소하는 경향을 보였다(Table 2). HPV 감 염 유전자형(단일/다중 감염)과 세포학적 진단과의 $\chi^{2}$ 교차분석 결 과에서 통계적으로 유의한 차이 $(p<0.05)$ 는 확인되지 않았다. 하 지만 악성화 과정에 따른 단일감염은 증가, 다중감염은 감소하였는 데 단일 감염에서 증가순서는 $\mathrm{LSIL}(68.5 \%), \mathrm{HSIL}$ (73.2\%), SCC (85.3\%)순으로 증가하였고 특히, Adenocarcinoma (AC)의 경우

Table 1. Human papilloma virus (HPV) infection according to age

\begin{tabular}{crrr}
\hline \multicolumn{1}{c}{ Age } & \multicolumn{1}{c}{ Positive } & \multicolumn{1}{c}{ Negative } & \multicolumn{1}{c}{ Total } \\
\hline $17 \sim 29$ & $145(59.2 \%)$ & $100(40.8 \%)$ & $245(100 \%)$ \\
$30 \sim 39$ & $384(44.7 \%)$ & $476(55.3 \%)$ & $860(100 \%)$ \\
$40 \sim 49$ & $527(39.4 \%)$ & $812(60.6 \%)$ & $1,339(100 \%)$ \\
$50 \sim 59$ & $436(39.4 \%)$ & $671(60.6 \%)$ & $1,107(100 \%)$ \\
$60 \sim 95$ & $342(46.2 \%)$ & $399(53.8 \%)$ & $741(100 \%)$ \\
Total & $1,834(42.7 \%)$ & $2,458(57.3 \%)$ & $4,292(100 \%)$ \\
\hline
\end{tabular}


Table 2. HPV prevalence in patients with different cytological diagnoses : single / multiple HPV infection and associated risk genotype

\begin{tabular}{|c|c|c|c|c|c|c|c|c|c|c|c|}
\hline \multirow{3}{*}{ Cytology } & \multicolumn{6}{|c|}{ Single HPV infection $(\mathrm{N}=262)$} & \multicolumn{4}{|c|}{ Multiple HPV infection $(\mathrm{N}=83)$} & \multirow{3}{*}{ Total N=345 (\%) } \\
\hline & \multicolumn{2}{|c|}{ OR } & \multicolumn{2}{|c|}{ LR } & \multicolumn{2}{|c|}{$H R$} & \multicolumn{2}{|c|}{$H R-L R$} & \multicolumn{2}{|c|}{$\mathrm{HR}-\mathrm{HR}$} & \\
\hline & $\mathrm{N}$ & $\%$ & $\mathrm{~N}$ & $\%$ & N & $\%$ & N & $\%$ & N & $\%$ & \\
\hline LSIL & 3 & 7.8 & 6 & 15.8 & 17 & 44.7 & 4 & 10.5 & 8 & 21.1 & $38(100.0)$ \\
\hline HSIL & 9 & 3.9 & 4 & 1.7 & 156 & 67.5 & 8 & 3.5 & 54 & 23.4 & $231(100.0)$ \\
\hline SCC & 2 & 3.3 & 0 & 0.0 & 50 & 82.0 & 0 & 0.0 & 9 & 14.8 & $61(100.0)$ \\
\hline$A C$ & 1 & 6.7 & 1 & 6.7 & 13 & 86.7 & 0 & 0.0 & 0 & 0.0 & $15(100.0)$ \\
\hline
\end{tabular}

LSIL, low-grade squamous intraepithelial lesion; HSIL, high-grade squamous intraepithelial lesion; SCC, squamous cell carcinoma; AC, adenocarcinoma; OR, others risk; LR, low risk; HR, high risk, HR-LR, high risk-low risk, HR-HR, high risk-high risk.

Table 3. HPV prevalence in patients with different cytological diagnoses : multiple HPV infection and associated number of HPV

\begin{tabular}{|c|c|c|c|c|c|c|c|c|c|c|c|}
\hline \multirow{2}{*}{ Cytology } & \multicolumn{3}{|c|}{ Number of $\mathrm{HPV}=2$} & \multicolumn{3}{|c|}{ Number of $\mathrm{HPV}=3$} & \multicolumn{3}{|c|}{ Number of HPV=4 } & \multicolumn{2}{|c|}{ Total } \\
\hline & $N$ & $\%$ & $p$ value & N & $\%$ & $p$ value & $\mathrm{N}$ & $\%$ & $p$ value & $\mathrm{N}$ & $\%$ \\
\hline LSIL & 10 & 83.3 & 0.698 & 2 & 16.7 & 0.916 & 0 & 0.0 & 0.508 & 12 & 100.0 \\
\hline HSIL & 48 & 77.4 & 0.416 & 11 & 17.7 & 0.715 & 3 & 4.8 & 0.305 & 62 & 100.0 \\
\hline SCC & 8 & 88.9 & 0.509 & 1 & 11.1 & 0.570 & 0 & 0.0 & 0.740 & 9 & 100.0 \\
\hline
\end{tabular}

Abbreviations are the same as those in Table 2.

는 $100 \%$ 를 보였다. 이에 비해 다중감염은 LSIL (31.5\%), HSIL (26.8\%), SCC (14.7\%)로 감소를 보였다.

$\mathrm{HPV}$ 다중감염 수와 세포학적 진단과의 연관성 및 교호작용을 확인하기 위해 로지스틱 회귀분석(logistic regression) 실시하였 다. 로지스틱 회귀분석 결과, 세포학적 진단에서 위험도가 높은 $\mathrm{HSIL}$ 에서 2개 다중감염 $(\mathrm{N}=48,77.4 \%)$, 3개 다중감염 $(\mathrm{N}=11$, $17.7 \%), 4$ 개 다중감염 $(\mathrm{N}=3,4.8 \%)$ 이 집중적으로 나타났지만 통계 적으로 유의한 차이 $(p<0.05)$ 는 확인되지 않았다(Table 3).

\section{3. 연령대 및 세포학적 진단에 따른 HPV 유전자형 분포}

$\mathrm{HPV}$ 단일감염 중 비정상적인 세포학적 진단은 262 명으로 262 건의 HPV 유전자형이 발견되었고, 다중감염은 83명의 환자 수에 서 186 건의 $\mathrm{HPV}$ 유전자형이 발견되었다. HPV 단일감염에서 연령 별 HPV 유전자형 분포를 보면 10 20대(n=18), 30대(n=74), 40 대 $(\mathrm{n}=66), 50$ 대 $(\mathrm{n}=54), 60$ 대 이상 $(\mathrm{n}=50)$ 이고 HPV 다중감염에서 는 10 20대 $(\mathrm{n}=20), 30$ 대 $(\mathrm{n}=52), 40$ 대 $(\mathrm{n}=61), 50$ 대 $(\mathrm{n}=21), 60$ 대 이상 $(n=30)$ 으로 나타났다. 단일감염에서 HPV 유전자형 분포를 확 인하면 HPV $16,58,18$, OR 순이고, 다중 감염에서는 HPV 16, 33, 35,58 형 빈도순으로 나타났다.

$\mathrm{HPV}$ 유전자형 분포와 연령대에 대한 통계적 유의성 $(p<0.05)$ 을 알아보기 위해, 종속변수에 각각의 HPV 감염 유전자형을 대입 하고 독립변수(요인분석)에 각각의 연령대를 대입하여 이분형 로 지스틱 회귀분석(binary variable logistic regression)을 실시하였 다. 단일감염에서는 OR이 30 50대에 통계적 유의성을 보였고,
다중감염에서는 $\mathrm{HPV} 35$ 형이 40 대( $\mathrm{n}=11, p=0.034)$ 에만 통계적 유의성을 보였다(Table 4).

$\mathrm{HPV}$ 단일감염 중 비정상적인 세포학적 진단 262건으로 $\mathrm{HPV}$ 유 전자형 분포를 보면 $\mathrm{HPV} 16,58,18,52$ 형, 편평세포 병변에 따라 $\mathrm{HPV} 16,58,52,18$, 31형 빈도순이었다. LSIL에서는 HPV 70, 58, OR, 16, 53, 56, 66형, HSIL에서는 HPV 16, 58, 52, 18형, SCC는 $\mathrm{HPV} 16,18,31,58$ 형, $\mathrm{AC}$ 는 HPV 18, 16, 70, OR형 빈도순으로 확인되었다.

비정상적 세포와 $\mathrm{HPV}$ 감염 유전자형들 간의 통계적 유의성 $(p<0.05)$ 을 알아보기 위해, 종속변수에 HPV 감염 유전자형을 대 입하고 독립변수(요인분석)에 비정상 세포학적 진단을 대입하여 로지스틱 회귀분석을 실시하였다. 모든 변수는 비정상 세포들만으 로 연관성을 조사하였기 때문에 대조군은 통계학적 조사 범주에 포 함하지 않았다. LSIL에서는 고위험군 HPV 16형과 저위험군 HPV 70형, HSIL에서는 고위험군 HPV 16, 31, 52, 58형이 통계적 유의 성을 보였다. $\mathrm{SCC}$ 에서는 고위험군 $\mathrm{HPV} 16,45$ 형 $\mathrm{AC}$ 에서는 고위 험군 18형만 통계적 유의성을 보였다(Table 5).

$\mathrm{HPV}$ 다중감염 중 비정상적인 $\mathrm{HPV}$ 유전자형 분포를 보면 $\mathrm{HPV}$ $16,33,35,58$ 형 빈도순이었다. 편평세포 병변에 따라 단일과 다중 감염을 모두 포함한 $\mathrm{HPV}$ 유전자형 분포를 보면 $\mathrm{HPV} 16,58,52$, 33,18 형 빈도순이다. LSIL에서는 HPV 70, 39, 52, 58, 66형, HSIL 에서는 HPV $16,33,35,58$ 형, SCC는 HPV 33, 58, 16, 35형 빈도 순으로 확인되었다.

비정상적 세포와 HPV 감염 유전자형들 간의 통계적 유의성 
42 Mi-Suk Park, et al. Genotype Analysis of HPV Infection in Accordance with Cytological Diagnoses

Table 4. HPV prevalence in patients with different cytological diagnoses : single/multiple HPV infection and associated age

\begin{tabular}{|c|c|c|c|c|c|c|c|c|c|c|c|c|c|c|c|c|c|}
\hline \multirow{2}{*}{$\begin{array}{l}\text { HPV } \\
\text { Type }\end{array}$} & \multicolumn{3}{|c|}{ below $20 \mathrm{~S}$} & \multicolumn{3}{|c|}{$30 \mathrm{~S}$} & \multicolumn{3}{|c|}{$40 S$} & \multicolumn{3}{|c|}{$50 \mathrm{~S}$} & \multicolumn{3}{|c|}{ over 605} & \multicolumn{2}{|c|}{ Total } \\
\hline & $N$ & $\%$ & $p$ value & $\mathrm{N}$ & $\%$ & $p$ value & N & $\%$ & $p$ value & $N$ & $\%$ & $p$ value & $\mathrm{N}$ & $\%$ & $p$ value & N & $\%$ \\
\hline \multicolumn{18}{|l|}{$\begin{array}{c}\text { Single } \\
H R\end{array}$} \\
\hline 16 & 7 & 5.9 & 0.258 & 36 & 30.5 & 0.135 & 34 & 28.8 & 0.094 & 22 & 18.6 & 0.268 & 19 & 16.1 & 0.266 & 118 & 100.0 \\
\hline 18 & 2 & 8.0 & 0.572 & 4 & 16.0 & 0.424 & 10 & 40.0 & 0.922 & 7 & 28.0 & 0.800 & 2 & 8.0 & 0.138 & 25 & 100.0 \\
\hline 31 & 2 & 14.3 & 0.576 & 4 & 28.6 & 0.798 & 2 & 14.3 & 0.888 & 2 & 14.3 & 0.796 & 4 & 28.6 & 0.353 & 14 & 100.0 \\
\hline 33 & & & & & & & & & & & & & 1 & 100.0 & - & 1 & 100.0 \\
\hline 39 & 1 & 100.0 & - & & & & & & & & & & & & & 1 & 100.0 \\
\hline 45 & & & & 3 & 75.0 & - & & & & 1 & 25.0 & - & & & & 4 & 100.0 \\
\hline 51 & & & & 0 & 0.0 & - & & & & 1 & 100.0 & - & & & & 1 & 100.0 \\
\hline 52 & 1 & 4.5 & 0.111 & 5 & 22.7 & 0.104 & 4 & 18.2 & 0.089 & 7 & 31.8 & 0.323 & 5 & 22.7 & 0.650 & 22 & 100.0 \\
\hline 53 & 1 & 50.0 & - & & & & & & & & & & 1 & 50.0 & - & 2 & 100.0 \\
\hline 56 & 1 & 16.7 & 0.653 & 1 & 16.7 & 0.974 & 1 & 16.7 & 0.974 & 1 & 16.7 & 0.904 & 2 & 33.3 & 0.369 & 6 & 100.0 \\
\hline 58 & 2 & 6.5 & 0.404 & 10 & 32.3 & 0.344 & 6 & 19.4 & 0.603 & 5 & 16.1 & 0.836 & 8 & 25.8 & 0.310 & 31 & 100.0 \\
\hline 59 & & & & & & & & & & & & & 1 & 100.0 & - & 1 & 100.0 \\
\hline 66 & & & & 1 & 20.0 & - & 2 & 40.0 & - & 2 & 40.0 & - & & & & 5 & 100.0 \\
\hline 68 & & & & 1 & 20.0 & - & & & & 2 & 40.0 & - & 2 & 40.0 & - & 5 & 100.0 \\
\hline \multicolumn{18}{|l|}{ LR } \\
\hline 6 & & & & 1 & 100.0 & - & & & & & & & & & & 1 & 100.0 \\
\hline 11 & 1 & 100.0 & & & & & & & & & & & & & & 1 & 100.0 \\
\hline 54 & & & & & & & 1 & 100.0 & - & & & & & & & 1 & 100.0 \\
\hline 70 & & & & 4 & 50.0 & 0.282 & 1 & 12.5 & 0.181 & 2 & 25.0 & 0.414 & 1 & 12.5 & 0.630 & 8 & 100.0 \\
\hline OR & & & & 4 & 26.7 & $0.023^{*}$ & 5 & 33.3 & $0.032^{*}$ & 2 & 13.3 & $0.017^{\star}$ & 4 & 26.7 & 0.441 & 15 & 100.0 \\
\hline \multicolumn{18}{|c|}{ Multiple- } \\
\hline 16 & 4 & 11.8 & 0.480 & 10 & 29.4 & 0.454 & 12 & 35.3 & 0.36 & 4 & 11.8 & 0.42 & 4 & 11.8 & 0.213 & 34 & 100.0 \\
\hline 18 & 2 & 33.3 & 0.999 & 0 & 0.0 & 1.000 & 2 & 33.3 & 0.999 & 2 & 33.3 & 0.999 & 0 & 0.0 & 0.232 & 6 & 100.0 \\
\hline 31 & 2 & 33.3 & 0.753 & 2 & 33.3 & 0.618 & 1 & 16.7 & 0.483 & 0 & 0.0 & 0.999 & 1 & 16.7 & 0.926 & 6 & 100.0 \\
\hline 33 & 1 & 3.1 & 0.538 & 7 & 21.9 & 0.312 & 12 & 37.5 & 0.229 & 4 & 12.5 & 0.499 & 8 & 25.0 & 0.194 & 32 & 100.0 \\
\hline 35 & 1 & 3.8 & 0.130 & 6 & 23.1 & 0.620 & 11 & 42.3 & $0.034^{*}$ & 3 & 11.5 & 0.140 & 5 & 19.2 & 0.853 & 26 & 100.0 \\
\hline 39 & 1 & 20.0 & - & 1 & 20.0 & - & 1 & 20.0 & - & 1 & 20.0 & - & 1 & 20.0 & - & 5 & 100.0 \\
\hline 45 & & & & 1 & 100.0 & - & & & & & & & & & & 1 & 100.0 \\
\hline 52 & 1 & 6.7 & 0.543 & 8 & 53.3 & 0.883 & 5 & 33.3 & 0.818 & 0 & 0.0 & 0.999 & 1 & 6.7 & 0.205 & 15 & 100.0 \\
\hline 53 & 1 & 20.0 & - & 1 & 20.0 & - & 1 & 20.0 & - & 1 & 20.0 & - & 1 & 20.0 & - & 5 & 100.0 \\
\hline 56 & 1 & 33.3 & - & 1 & 33.3 & - & & & & 1 & 33.3 & - & & & & 3 & 100.0 \\
\hline 58 & 1 & 3.8 & 0.458 & 10 & 38.5 & 0.912 & 7 & 26.9 & 0.610 & 2 & 7.7 & 0.385 & 6 & 23.1 & 0.424 & 26 & 100.0 \\
\hline 59 & & & & & & & 1 & 100.0 & - & 0 & & & & & & 1 & 100.0 \\
\hline 66 & 1 & 12.5 & 0.326 & 0 & 0.0 & 0.998 & 4 & 50.0 & 0.346 & 0 & 0.0 & 0.999 & 3 & 37.5 & 0.133 & 8 & 100.0 \\
\hline \multicolumn{18}{|l|}{$L R$} \\
\hline 6 & & & & 1 & 100.0 & - & & & & & & & & & & 1 & 100.0 \\
\hline 11 & & & & 1 & 20.0 & - & I & 20.0 & - & 2 & 40.0 & - & 1 & 20.0 & - & 5 & 100.0 \\
\hline 40 & 1 & 25.0 & - & 1 & 25.0 & - & 1 & 25.0 & - & 1 & 25.0 & - & & & & 4 & 100.0 \\
\hline 70 & 3 & 37.5 & 0.328 & 2 & 25.0 & 0.216 & 2 & 25.0 & 0.220 & 0 & 0.0 & 0.999 & 1 & 12.5 & 0.667 & 8 & 100.0 \\
\hline
\end{tabular}

*Data with $p<0.05$ are shown.

$\mathrm{HR}$, high risk; LR, low risk; OR, others risk.

( $p<0.05)$ 을 알아보기 위해, 종속변수에 HPV 감염 유전자형을 대 입하고 독립변수(요인분석)에 비정상 세포학적 진단을 대입하여 로지스틱 회귀분석을 실시하였다. LSIL에서는 고위험군 HPV 39 형과 66형, 저위험군 HPV 70형에서 통계적 유의성을 보였고, HSIL에서는 고위험군 HPV 16형, 저위험군 HPV 70형이 통계적 유 의성을 보였다. SCC에서는 고위험군 HPV 18형만 통계적 유의성 을 보였다(Table 6).

\section{고 찰}

자궁경부암은 세계적으로 여성 암 발생률이 3 위, 암 사망률은 4 위(Ferlay 등, 2010)로 암 발생의 주요 인자는 성 접촉에 의한 HPV 감염이다. 180 종의 HPV 유전자형 중 30 40종의 유전자형이 여 성 생식기에 감염을 일으킨다.

본 연구는 2012년 한 해 동안 대학병원 병리과에 접수된 HPV 
Table 5. HPV genotype prevalence among single infection patients diagnosed with cytology

\begin{tabular}{|c|c|c|c|c|c|c|c|c|c|c|c|c|}
\hline \multirow{2}{*}{$\begin{array}{l}\text { HPV } \\
\text { type }\end{array}$} & \multicolumn{3}{|c|}{ LSIL } & \multicolumn{3}{|c|}{ HSIL } & \multicolumn{3}{|c|}{$\mathrm{SCC}$} & \multicolumn{3}{|c|}{$A C$} \\
\hline & $N$ & $\%$ & $p$ value & $\mathrm{N}$ & $\%$ & $p$ value & $N$ & $\%$ & $p$ value & $\mathrm{N}$ & $\%$ & $p$ value \\
\hline \multicolumn{13}{|l|}{$H R$} \\
\hline 16 & 2 & 7.7 & $0.014^{*}$ & 80 & 47.3 & $0.001^{*}$ & 31 & 59.6 & $0.002^{*}$ & 5 & 33.3 & 0.245 \\
\hline 18 & 1 & 3.8 & 0.558 & 11 & 6.5 & 0.461 & 5 & 9.6 & 0.052 & 8 & 53.3 & $0.001^{*}$ \\
\hline 31 & 1 & 3.8 & 0.958 & 10 & 5.9 & $0.043^{*}$ & 3 & 5.8 & 0.506 & & & \\
\hline 33 & & & & & & & 1 & 1.9 & 0.193 & & & \\
\hline 39 & 1 & 3.8 & 0.061 & & & & & & & & & \\
\hline 45 & 1 & 3.8 & 0.164 & 1 & 0.6 & 0.234 & 2 & 3.8 & $0.015^{*}$ & & & \\
\hline 51 & & & & 1 & 0.6 & 0.182 & & & & & & \\
\hline 52 & 1 & 3.8 & 0.660 & 20 & 11.8 & $0.001^{*}$ & 1 & 1.9 & 0.155 & & & \\
\hline 53 & 2 & 7.7 & 0.999 & & & & & & & & & \\
\hline 56 & 2 & 7.7 & 0.058 & 3 & 1.8 & 0.758 & 1 & 1.9 & 0.926 & & & \\
\hline 58 & 3 & 11.5 & 0.497 & 25 & 14.8 & $0.001^{*}$ & 3 & 5.8 & 0.262 & & & \\
\hline 59 & & & & 1 & 0.6 & 0.114 & & & & & & \\
\hline 66 & 2 & 7.7 & 0.065 & 2 & 1.2 & 0.664 & 1 & 1.9 & 0.409 & & & \\
\hline 68 & 1 & 3.8 & 0.236 & 2 & 1.2 & 0.850 & 2 & 3.8 & 0.289 & & & \\
\hline \multicolumn{13}{|l|}{$L R$} \\
\hline 6 & & & & 1 & 0.6 & 0.443 & & & & & & \\
\hline 11 & 1 & 3.8 & 1.000 & & & & & & & & & \\
\hline 54 & & & & 1 & 0.6 & 0.690 & & & & & & \\
\hline 70 & 5 & 19.2 & $0.010^{*}$ & 2 & 1.2 & 0.092 & & & & 1 & 6.7 & 0.105 \\
\hline OR & 3 & 11.5 & 0.058 & 9 & 5.3 & 0.286 & 2 & 3.8 & 0.846 & 1 & 6.7 & 0.380 \\
\hline Total & 26 & 100.0 & & 169 & 100.0 & & 52 & 100.0 & & 15 & 100.0 & \\
\hline
\end{tabular}

Abbreviations are the same as those in Table 2 and 4 .

*Data with $p<0.05$ are shown.

Table 6. HPV genotype prevalence among mutiple infection patients diagnosed with cytology

\begin{tabular}{|c|c|c|c|c|c|c|c|c|c|}
\hline \multirow{2}{*}{$\begin{array}{l}\text { HPV } \\
\text { type }\end{array}$} & \multicolumn{3}{|c|}{ LSIL } & \multicolumn{3}{|c|}{ HSIL } & \multicolumn{3}{|c|}{$\mathrm{SCC}$} \\
\hline & $N$ & $\%$ & $p$ value & N & $\%$ & $p$ value & $\mathrm{N}$ & $\%$ & $p$ value \\
\hline \multicolumn{10}{|l|}{$\mathrm{HR}$} \\
\hline 16 & 2 & 7.7 & 0.218 & 29 & 20.6 & $0.048^{*}$ & 3 & 15.8 & 0.487 \\
\hline 18 & 1 & 3.8 & 0.959 & 4 & 2.8 & 0.088 & 1 & 5.3 & $0.044^{*}$ \\
\hline 31 & 2 & 7.7 & 0.764 & 2 & 1.4 & 0.053 & 2 & 10.5 & 0.059 \\
\hline 33 & 2 & 7.7 & 0.892 & 25 & 17.7 & 0.570 & 5 & 26.3 & 0.101 \\
\hline 35 & 2 & 7.7 & 0.466 & 21 & 14.9 & 0.390 & 3 & 15.8 & 0.807 \\
\hline 39 & 3 & 11.5 & $0.001^{*}$ & 1 & 0.7 & 0.059 & 1 & 5.3 & 0.749 \\
\hline 45 & & & & 1 & 0.7 & 0.710 & & & \\
\hline 52 & 3 & 11.5 & 0.274 & 12 & 8.5 & 0.880 & & & \\
\hline 53 & & & & 5 & 3.5 & 0.136 & & & \\
\hline 56 & 1 & 3.8 & 0.510 & 2 & 1.4 & 0.630 & & & \\
\hline 58 & 3 & 11.5 & 0.659 & 19 & 13.5 & 0.904 & 4 & 21.1 & 0.399 \\
\hline 59 & & & & 1 & 0.7 & 0.710 & & & \\
\hline 66 & 3 & 11.5 & $0.040^{*}$ & 5 & 3.5 & 0.547 & & & \\
\hline \multicolumn{10}{|l|}{$L R$} \\
\hline 6 & & & & 1 & 0.7 & 0.710 & & & \\
\hline 11 & & & & 5 & 3.5 & 0.226 & & & \\
\hline 40 & & & & 4 & 2.8 & 0.446 & & & \\
\hline 70 & 4 & 15.4 & $0.007^{*}$ & 4 & 2.8 & $0.029^{*}$ & & & \\
\hline Total & 26 & 100.0 & & 141 & 100.0 & & 19 & 100.0 & \\
\hline
\end{tabular}

Abbreviations are the same as those in Table 2, 4 and 5 .

*Data with $p<0.05$ are shown. 
DNA chip검사 4,292건을 대상으로 하였으며 그 결과 HPV 양 성은 1,834 건(42.7\%), 음성은 2,458 건(57.3\%)이었다. 1999년 Walboomers 등에 따르면 HPV 감염은 성 접촉에 의해 감염되므로 20 30대에서 가장 높은 유병률을 보이고 연령이 증가하면 감소하 는 양상을 보인다고 하였는데 본 연구에서도 같은 결과인 17 29 세(59.8\%)를 제외하고는 각 연령대에서 양성률이 음성률보다 더 낮았다. 연령에 대한 선행 논문에 따르면 30세 미만 여성에서 양성 률이 높고 30세 이후 연령대에서 낮아지기 시작하여 60세 이상 때 다시 높아지는 U형의 모양을 보이는데 폐경기 혹은 폐경 후에 잠복 해 있던 HPV가 재활성화 되어 2차 절정을 갖는데 본 연구 결과와 일치하였다(Lazcano-Ponce 등, 2001).

단일감염에 비교하여 다중감염 시 고위험 자궁경부 종양 형성 예측인자로 침윤성 자궁경부암과 관계있으며 지속감염을 유발하여 HPV 감염에 대한 면역력을 저하시키는(Fife 등, 2001; Sasagawa 등, 2001) 보고되고 있어서 세포학적 진단에 따른 단일/다중 감염 에 분포를 조사하였다. 그 결과 단일감염은 262 건(75.9\%), 다중 감 염은 83건(24.1\%)이었고 Liaw 등(2001) 보고처럼 20 50\% 범위 안에 발견되었다. 침윤성 암에서 단일감염보다 다중감염이 높게 나 타날 것으로 사료되었지만 암화 과정이 진행될수록 단일감염이 높 게 나타나고 다중감염은 감소 및 $\mathrm{AC}$ 는 단일감염에만 나타나 Gargiulo 등(2007) 보고와 유사한 양상을 보였다. 그 이유로는 한 HPV 유전자형의 E2-encoded protein이 다른 HPV 유전자형의 $\mathrm{E} 6$ 와 $\mathrm{E} 7$ 의 $\mathrm{ORF}$ 를 억제하는 효과를 나타내므로 다중 감염된 세포 는 먼저 감염된 $\mathrm{HPV}$ 의 면역반응으로 두 번째 감염 $\mathrm{HPV}$ 를 제거하 는 시간이 필요하므로 세포학적 비정상 소견을 가진 군에는 다중감 염의 유병율이 낮으며(Kim 등, 2003), 이는 자궁경부의 암화과정 이 진행될수록 특정 $\mathrm{HPV}$ 유전자형이 지속적인 감염으로 남게 되고 동반된 HPV는 암화과정이 진행되면서 자연 소실되어 단일감염이 발견된다고 생각한다.

암화과정에서 특정 HPV 유전자형과의 상관관계를 알아보고자 단일감염에서 통계적 분석한 결과 LSIL은 HPV 16, 70형, HSIL에 서는 HPV $16,31,52,58$ 형, SCC에서는 HPV 16, 45형, AC에서는 $\mathrm{HPV} 18$ 형만이 통계적 유의성을 보였고, 다중감염에서 분석한 결 과 LSIL은 HPV 39, 66, 70형, HSIL에서는 HPV 16, 70형, SCC에서 는 HPV 18 형만이 유의성을 보였다. 특히, 자궁경부 편평세포 병변 에서 모두 HPV 16형, 샘암종에서는 HPV 18형이 유의성을 보였고 자궁경부 편평세포암에서 $\mathrm{HPV}$ 16형(59.6\%)과 샘암종에서는 $\mathrm{HPV} 18$ 형(53.3\%)로 이런 결과는 암과 특정 HPV 유전자형의 상관 관계가 있다고 생각되며 이와 비슷한 연구 결과들도 보고되고 있다 (Bosch 등, 1995; Park and Cho, 2013). 원인으로는 각각의 HPV 유전자형들이 약간씩 다른 세포군으로 변형되는데, HPV 16형은
편평 성숙을 유발하고 HPV 18형에 의해 선형 분화를 유도되어 진 다고 본다(Wilczynski 등, 1988).

자궁경부 편평세포 병변에서 단일감염에서 $\mathrm{HPV}$ 유전자형 분포 를 보면 HPV $16,58,52,18,31$ 형 빈도순이었고 단일/다중 감염을 포함한 HPV 유전자형 분포는 HPV $16,58,52,33,18$ 형 빈도순으 로 확인되었다. 각 나라 및 지역별 HPV 유전자형의 분포도가 차이 를 보이는데 이탈리아의 경우 HPV $16,52,18,31$ 형, 중국은 HPV $16,58,11,18$ 형, 일본은 HPV 16, 52, 58, 18형 빈도순(Chan 등, 1999; Sasagawa 등, 2001; Garglulo 등, 2007)으로 차지하였다. 우리나라에서는 전북 군산에서 고위험군은 HPV $16,52,58,53$ 형, 저위험군 HPV 70, 6형 빈도순(Lee 등, 2011)이었고 Hong 등 (2009) 결과로는 서울은 HPV 16, 58, 18형, 대전은 HPV 16, 58, 56형, 대구는 HPV 16, 58, 18형, 마지막 호남은 HPV 16, 58, 18형 빈도순으로 HPV 16형은 전 세계 뿐만 아니라 우리나라에도 가장 많은 분포를 차지하였고 그다음 HPV 58형이다.

현재 HPV 예방 백신은 HPV 6, 11, 16, 18형이 있는데 HPV 6, 11형은 저등급 상피내 병변에 예방효과가 있고, HPV 16, 18형은 자궁경부암과 고등급 상피내 병변에 효과를 가지고 있다. 자궁경부 암 예방 백신 중 하나인 Cervarix는 HPV 16, 18형 외에 HPV 31, 33, 45형에 교차 예방 효과가 있고 Gardasil은 HPV 45, 31형이 CIN 병변 예방에 일부 효과가 보고되고 있다(Kim 등, 2010).

세포학적 진단에 따른 HPV 유전자형은 HPV 16, 58, 52, 18, 31 형의 빈도순으로 많은 분포를 확인 할 수 있고 이번 연구에서 다중 감염이 암화 과정으로 진행시 예측 인자로 보이는 통계적 유의성이 나타나지 않아 추가적인 연구가 좀 더 필요한 것으로 사료된다. 하 지만, 단일감염 중 HPV $16,18,31,45,52,58$ 형이 암화 과정으로 진행시 관련성이 있는 것으로 통계적 유의성이 나타나 향후 $\mathrm{HPV}$ 예방 백신을 구축하는데 유용성이 있다고 생각된다.

Acknowledgements: Thanks to Hyun-Ho Kim for statistical analysis.

Funding: None

Conflict of interest: None

\section{References}

1. Back OC. Correlation of Expression of p53, Cylcin D1 and Galectin-3 in Papillary Carcinoma and Follicular Carcinoma. Korean J Clin Lab Sci. 2013, 45:32-36.

2. Bosch FX, Manos MM, Muñoz N, Sherman M, Jansen AM, Peto J, et al. Prevalence of papillomavirus in cervical cancer: a worldwide perspective. International biological study on cervical cancer (IBSCC) Study Group. J Natl Cancer Inst. 1995, 87: 
796-802.

3. Chan PK, Li WH, Chan MY, Ma WL, Cheung JL, Cheng AF : High prevalence of human papillomavirus type 56 in China women with cervical cancer and precancerous lesions. J Med Virol. 1999, 59:232-238.

4. Daling JR, Madeleine MM, McKnight B, Carter JJ, Wipf GC, Ashley R, et al. The relationship of human papillomavirus-related cervical tumors to cigarette smoking, oral contraceptive use, and prior herpes simplex virus type 2 infection. Cancer Epidemiol Biomarkers Prev. 1996, 5:541-548.

5. Ferlay J, Shin HR, Bray F, Forman D, Mathers C, Parkin DM. Estimates of worldwide burden of cancer in 2008: GLOBOCAN 2008. Int J Cancer. 2010, 127: 2893-2917.

6. Fife KH, Cramer HM, Schroeder JM, Brown DR. Detection of multiple human papillomavirus types in the lower genital tract correlates with cervical dysplasia. J Med Virol. 2001, 64:550-559.

7. Franco EL, Villa LL, Sobrinho JP, Prado JM, Rousseau MC, Deisy $\mathrm{M}$, et al. Epidemiology of acquisition and clearance of cervical human papillomavirus infection in women from a high risk area for cervical cancer. J Infect Dis. 1999, 180:1415-1423.

8. Gargiulo F, De Francesco MA, Schreiber C, Ciravolo G, Salinaro F, Valloncini B, Manca N. Prevalence and distribution of single and multiple HPV infections in cytologically abnormal cervical samples from Italian women. Virus Res. 2007, 125: 176-182.

9. Hong SR, Kim IS, Kim DW, Kim MJ, Kim AR, Kim YO, et al. Prevalence and Genotype distribution of cervical human papillomavirus DNA in Korean Women : A Multicenter Study. The Korean J of Pathology. 2009. 43:342-350.

10. Kastan MB, Zhan Q, el-Deiry WS, Carrier F, Jacks T, Walsh WV, et al. A mammalian cell cycle check-point pathway utilizing p53 and GADD45 is defective in ataxia-telangietasia. Cell. 1992, 71:587-597.

11. Kim CJ, Park TC and Park JS. Efficacy of human papillomavirus vaccines including cross protection : A review of recent evidence. Korean J Obstetrics \& Gynecology. 2010, 53:103-118.

12. Kim DY and Lee HP. The human papillomavirus types 16 and 18 infection and expression of $\mathrm{p} 53$ protein in adenocarcinoma of the cervix. Korean J Obstetrics \& Gynecology. 1998, 41:3007-3015.

13. Kim PY, Lee DW, Seo JH, Sunwoo JG, Bae DH, Jeong DJ. A study for the prevalence of high-risk HPV subtype in uterine cervical neoplasia of korean women. Korean J Obstetrics \& Gynecology. 2003, 46:2005-2012.

14. Lazcano-Ponce E, Herrero R, Muñoz N, Cruz A, Shah KV, Alonso P, et al. Epidemiology of HPV infection among Mexican women with normal cervical cytology. Int J Cancer. 2001, 91:412-420.

15. Lee JR, Seop SE, Lee HH, Kim SR, Park JH, Hwang SO, et al. Clinical significance of HPV DNA test for management of pa- tients with diagnosis of atypical squamous cells of undetermined significance / Low-grade squamous intraepithelial lesions. Korean J Obstetrics \& Gynecology. 2003, 46:268-275.

16. Lee TH, Hyun SH, Kim IS. The histopathological examination for diagnosis of MALT lymphoma in the stomach. Korean J Clin Lab sci. 2014, 46:91-98.

17. Lee YJ, Jung JH, Jung DY. The Relationship between Papanicolaou Smear Test and Human Papilloma Virus DNA Chip Test in the Uterine Cervix. Korean J Clin Lab Sci. 2011, 43:26-32.

18. Liaw KL, Hildesheim A, Burk RD, Gravitt P, Wacholder S, Manos $\mathrm{MM}$, et al. A prospective study of human paillomavirus(HPV) type 16 DNA detection by polymerase chain reaction and its association with acquisition and persistence of other HPV types. $J$ infect Dis. 2001, 183:8-15.

19. Lorincz AT, Reid R, Jenson BA, Greenberg MD, Lancaster W, Kurman RJ. Human papillomavirus infection of the cervix: Relative risk associations of 15 common anogenital types. Obstetrics \& Gynecology. 1992, 79:328-337.

20. Park MS and Cho HY. Genotype analysis of human papillomavirus infection associated with abnormal cervical tissues in Gwangju and Jeonnam, Korea. Journal of The Korea Society of Health Informatics and Statistics. 2013, 38:1-12.

21. Sasagawa T, Basha W, Yamazaki H, Inoue M. High-risk and multiple human papillomavirus infections associated with cervical abnormalities in Japanese women. Cancer Epidemiol Biomarkers Prev. 2001, 10:45-52.

22. Soto-De Leon S, Camargo M, Sanchez R, Munoz M, Perez-Prados A, Purroy A, et al. Distribution patterns of infection with multiple types of human papillomaviruses and their association with risk factors. PLOS ONE. 2011, 6:e14705.

23. Tolstrup J, Munk C, Thomsen BL, Svare E, van den Brule AJ, $\mathrm{Gr} \varnothing$ nbaek M, et al. The role of smoking and alcohol intake in the development of high-grade squamous intraepithelial lesions among high-risk HPV-positive women. Acta Obstet Gynecol Scand. 2006, 85:1114-1119.

24. Walboomers JM, Jacobs MV, Manos MM, Bosch FX, Kummer JA, Shah KV, et al. Human papillomavirus is a necessary cause of invasive cervical cancer worldwide. J Pathol. 1999, 189:12-19.

25. Wilczynski SP, Bergen S, Walker J, Liao SY, Pearlman LF. Human papillomaviruses and cervical cancer : Analysis of histopathologic features associated with different viral types. Hum Pathol. 1988, 19:697-704.

26. Yim SB, Song ES, Lee DH, Kim SR, Park JH, Hwang SO, et al. Clinical significance of HPV DNA chip test in the management of atypical squamous cells of undetermined significance. Korean J Obstetrics \& Gynecology. 2003, 46:2451-2457. 